\title{
Fatty acid composition of three species of Codium (Bryopsidales, Chlorophyta) in Chile
}

Composición de ácidos grasos en tres especies del género Codium (Bryopsidales, Chlorophyta) de Chile

\author{
Franz Goecke ${ }^{1}$, Víctor Hernández ${ }^{1}$, Magalis Bittner ${ }^{1}$, Mariela González ${ }^{2}$, \\ José Becerra ${ }^{1}$ and Mario Silva ${ }^{1}$
}

\begin{abstract}
${ }^{1}$ Laboratorio de Química de Productos Naturales, Departamento de Botánica, Facultad de Ciencias Naturales y Oceanográficas, Universidad de Concepción, Casilla 160-C, Concepción, Chile. jbecerra@udec.cl

${ }^{2}$ Laboratorio de Ficología, Departamento de Botánica, Facultad de Ciencias Naturales y Oceanográficas, Universidad de Concepción, Casilla 160-C, Concepción, Chile
\end{abstract}

\begin{abstract}
Resumen.- Las algas poseen patrones de composición lipídica particulares de acuerdo a su identidad específica. En el presente trabajo se identificaron y compararon los principales ácidos grasos de dos especies endémicas del género Codium presente en Chile: $C$. dimorphum y $C$. fernandezianum; y de la especie introducida $C$. fragile. El principal ácido graso en el género fue el ácido palmítico (28-54\%), seguido del ácido oleico y del ácido linolénico. Se confirma por primera vez, la presencia de ácido hexadecatrienoico (C16:3), ácido graso propuesto como característico del género Codium, el cual puede aplicarse en estudios quimiotaxonómicos a nivel mundial.
\end{abstract}

Palabras clave: Algas, composición química, lípidos, ácido hexadecatrienoico

\begin{abstract}
The fatty acid compositions of algae show characteristic patterns accoding to species. This paper is the first to identify and compare the main fatty acids of the two endemic Codium species: $C$. dimorphum and $C$. fernandezianum found in Chile. In addition the fatty acids of the introduced species $C$. fragile were investigated. Palmitic acid was shown to be the main fatty acid, comprising between 28 to $54 \%$, followed by oleic and linolenic acids. We also confirm, for the first time, the presence of hexadecatrienoic acid (C16:3) in all three species, which is suggested to be a characteristic fatty acid for Codium genus, so this can be used in chemotaxonomy for these species around the world.
\end{abstract}

Key words: Algae, chemical composition, lipids, hexadecatrienoic acid

\section{INTRODUCTION}

There are about 100 species of Codium Stackhouse known around the world (Xu et al. 1998); three of them are native to Chile (Ramírez \& Santelices 1991). The genus Codium belongs to the family Codiaceae (Chlorophyta), and is characteristically organized in branches that form spongy, dark green, coenocytic thalli of intertwined filaments (Hoffmann \& Santelices 1997).

Lipid extracts obtained from Codium species have been shown to exhibit antibacterial, antiviral, antifungal and cytotoxic activities. A variety of sterols, fatty acids and terpenes are responsible for these activities (Caccamese $e t$ al. 1981). Due to their ability to produce polyunsaturated fatty acids C:18 and C:20 (PUFAs), marine algae have attracted considerable attention from researchers all over the world in the last two decades (Dembitsky et al. 2003). The nutritional value of fatty acids is indisputable, they are important components in the cellular structure, take part in the production of some hormones and bile salts, and have important regulatory functions for cellular activity and gene expression. In addition they are related to the prevention and treatment of atherosclerosis, thrombosis, arthritis and cancer, mainly through their metabolic conversion into prostaglandins, thromboxanes and leucotriens (Ip 1997). They also have hypocholesterolemic, immunostimulant and antioxidant properties (Sanhueza et al. 2002).

The fatty acid composition of algae is complex and there is a greater variety in algae than in vascular plants (Dembitsky et al. 2003). The lipid composition of red, brown, and green algae, belonging to different classes, orders, families and genera presents distinguishing features that are taxonomically valuable. Such fatty acid patterns are characteristic for different algal divisions. In green algae $\mathrm{C} 16$ and $\mathrm{C} 18$ PUFAs have been shown to be generally the most abundant (Khotimchenko 2003, Graeve et al. 2002). 
In a study considering six Codium species, $\mathrm{Xu}$ et al. (1998) detected 37 fatty acids. They determined palmitic acid (C16:0) (25\%-45\%) to be the most abundant, followed by oleic acid (C18:1), linolenic acid (C18:3), myristic acid (C14:0) and hexadecatrienoic acid (C16:3). They also reported on linolenic, arachidonic and eicosapentaenoic acids in concentrations of $1-10 \%$ in all taxa. Recently, in the northern Chile, Ortiz et al. (2009) detected 19 fatty acids in Codium fragile. They found linolenic acid to be the main fatty acid, making up $24.6 \%$ of the total fatty acid content, followed by palmitic $(17.74 \%)$, stearic $(17.38 \%)$ and oleic (12.25\%) acids.

In recent decades, these lipids have sparked the interest of chemotaxonomists. It has been proposed hexadecatetraenoic acid (C16:4) as taxonomically important for green algae, with only trace appearances in higher plants. But for years, hexadecatrienoic acid (C16:3) has been considered to be a characteristic fatty acid of the family Codiaceae, considered as the most important chemotaxonomic feature in the genus (Dembitsky et al. 2003, Khotimchenko 2003). However, C16:3 could not be detected in some Codium species by other researchers (Aliya et al. 1991, 1992, Hainaux et al. 1998, Ortiz et al. 2009). In this current investigation we describe the fatty acid composition of the two endemic Codium species in Chile (C. fernandezianum Setchell, C. dimorphum Svedelius) and one other recently introduced species $(C$. fragile (Suringar) Hariot).

\section{Material And Methods}

\section{Collection of Biological Material}

Codium fernandezianum was collected from the Robinson Crusoe Island in the Juan Fernández Archipelago

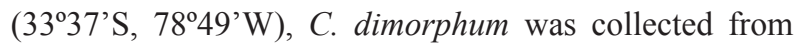
Horcón Cove (3340'S, $\left.79^{\circ} 00^{\prime} \mathrm{W}\right)$ and Codium fragile was obtained from Caldera Bay (27 $03^{\prime}$ 'S, $\left.70^{\circ} 51^{\prime} \mathrm{W}\right)$. The macroalgae were manually collected by SCUBA diving. The postrate algae $C$. dimorphum was collected with a trowel. Epiphytes were removed carefully with tweezers. The cleaned algae were stored at $-20^{\circ} \mathrm{C}$ until further processing in the laboratory.

Part of the macroalgae was fixed in $96 \%$ ethanol for its taxonomic identification. Algae were identified by examination of the utricles and fronds, dichotomies, presence of filaments, and reproductive structures (Hoffmann \& Santelices 1997, Campbell 1999).

Fresh samples $(3-5 \mathrm{~kg})$ of each of the three algae were cut into pieces separately. The pieces were extracted with methanol for 3 days in a $5 \mathrm{~L}$ extraction flask, protected from light and shaken every day by hand (modified from Dembitsky et al. 2003). Fresh algae contain a great amount of water, so extraction of mebolites can be better achieved by methanol, which is a polar solvent. The extracts were then filtered and concentrated under low pressure with a

Table 1. Mean values of the percentage of total fatty acid content in the Codium species studied herein. Numbers refer to peaks in figure 1 / Valores promedio del porcentaje del contenido de ácidos grasos total en las especies de Codium estudiadas. Los números corresponden a los picos en figura 1

\begin{tabular}{lccc}
\hline \multicolumn{1}{c}{ Fatty acid } & $\begin{array}{c}\text { C. fernandezianum } \\
\text { \% }\end{array}$ & $\begin{array}{c}\text { C. dimorphum } \\
\%\end{array}$ & $\begin{array}{c}\text { C. fragile } \\
\%\end{array}$ \\
\hline Myristic acid (C14:0) & 0.49 & 0.34 & 0.82 \\
Palmitic acid (C16:0) & 29.27 & 54.49 & 28.22 \\
(C16:2) & 1.74 & 1.68 & 0.74 \\
Hexadecatrienoic acid (16:3) & 9.57 & 7.25 & 7.50 \\
Stearic acid (C18:0) & 0.50 & 0.24 & 0.58 \\
Oleic acid (C18:1) & 15.14 & 20.39 & 5.20 \\
Linoleic acid (C18:2) & 8.25 & 2.17 & 0.74 \\
Linolenic acid (C18:3) & 16.93 & 9.83 & 6.74 \\
Arachidic acid (C20:0) & 0.55 & 0.34 & 4.22 \\
Arachidonic acid (C20:4) & 6.41 & 0.80 & 3.10 \\
Behenic acid (C22:0) & 2.65 & 1.68 & 2.26 \\
Total SAFA & 30.81 & 55.41 & 33.84 \\
Total MUFA & 15.14 & 20.39 & 5.20 \\
Total PUFA & 42.90 & 21.73 & 18.82 \\
\hline
\end{tabular}




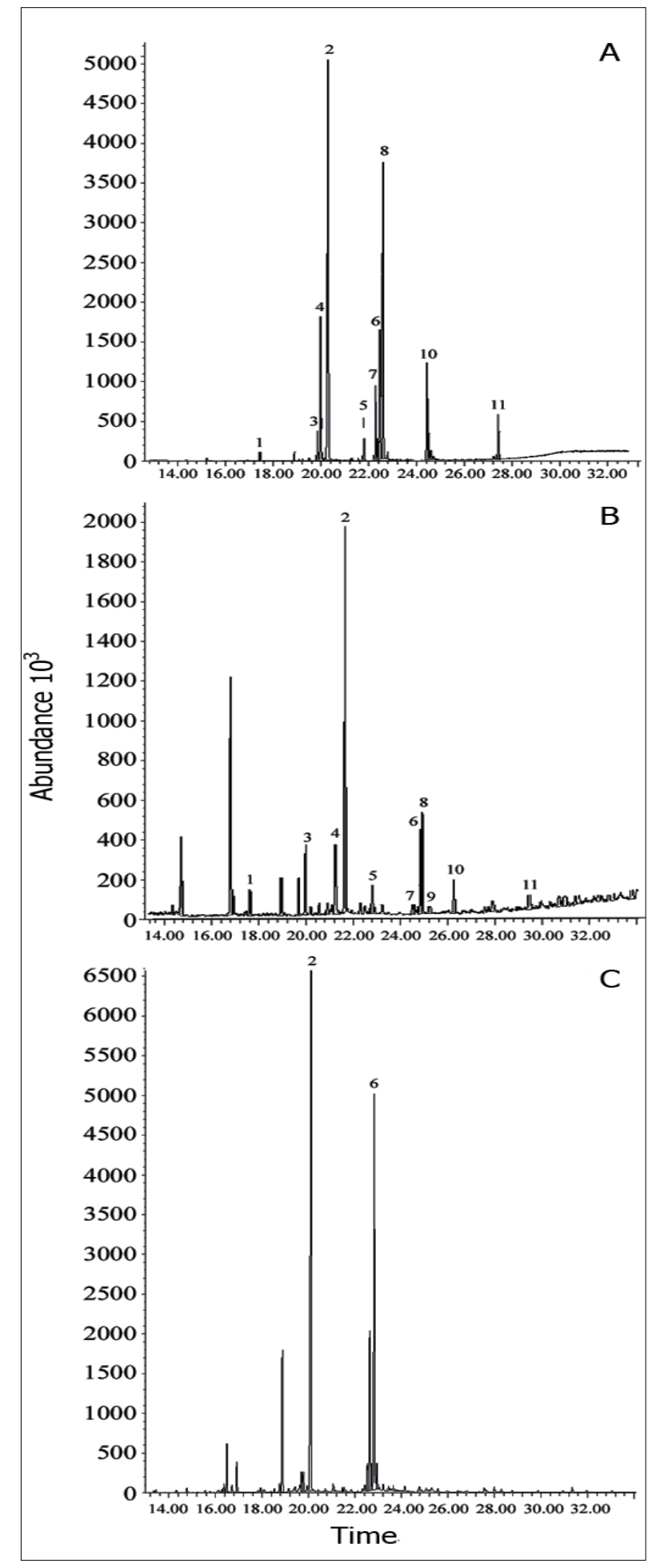

Figure 1. Fatty acids amounts of the green macroalgae, A) Codium fernandezianum, B) Codium fragile and C) Codium dimorphum and rentention times $(\mathrm{min})$ / Cantidad de ácidos grasos de las macroalgas clorofíceas, A) Codium fernandezianum, B) Codium fragile y C) Codium dimorphum obtenidos en el presente estudio y tiempos de retención ( $\mathrm{min})$ rotary evaporator Heidolph ${ }^{\circledR}$ Laborota. Eighty grams of total extract were obtained.

The total extracts were fractionated with solvents of increasing polarity (hexane, dichloromethane, ethyl acetate, distilled water) in a liquid-liquid separation device. The fractions obtained were analyzed using thin layer chromatography (TLC) and Gas ChromatographyMass Spectrometry (GC-MS).

Lipids were extracted according to Khotimchenko (2003). Two milligrams of the samples (hexanic and dichloromethanic fractions) were combined before methylation. The fatty acids present were derivatized, converting them into methyl esters by using $1 \% \mathrm{KCl}$ in $\mathrm{MeOH}$ and $5 \% \mathrm{HCl}$ in $\mathrm{MeOH}$ (Dembitsky et al. 2003). The fatty acid methyl esters (F.A.M.E.s) were then identified through GC-MS. The analyses were done in duplicates.

The identification of the obtained compounds was done with gas chromatography with flame ionization detection (GC-FID) and mass detection (GC-MS). Mass analysis was carried out in a Chromatograph Hewlett Packard 5890 Series II (California, USA) with a mass detector Hewlett Packard model 5972, Series. Gas carrier was helium electronic grade, with a flux of $1 \mathrm{ml} \mathrm{seg}^{-1}$, injector was $275^{\circ} \mathrm{C}$, detector temperature $300^{\circ} \mathrm{C}$, and the program for oven temperature was $100^{\circ} \mathrm{C}$ for the first $5 \mathrm{~min}$, and increased $10^{\circ} \mathrm{C}$ per minute until reaching $275^{\circ} \mathrm{C}$, with a final time of $15 \mathrm{~min}$. Chromatographic fused silica column was a HP-5MS (J\&W Scientific) of $30 \mathrm{~m}$, internal diameter of $0.25 \mathrm{~mm}$ and a phase thickness of $0.25 \mu \mathrm{m}$. Standards (F.A.M.E. Mix C14-C22, C20:1-C20:5) were purchased from SUPELCO (Bellefonte, PA, USA).

\section{Results}

A total of 11 fatty acids were identified in all samples of Codium dimorphum, C. fernandezianum, and C. fragile (Table 1). There were similar fatty acid compositions among the three species. The main fatty acids in descending order were palmitic (C16:0), oleic (C18:1), linoleic (C18:2), linolenic (C18:3) and hexadecatrienoic (C16:3) acids.

Total saturated fatty acids (SAFA) in the studied macroalgae accounted for $30 \%$ to $55 \%$ of all fatty acids. Total monounsaturated fatty acids (MUFA) accounted for $5 \%$ to $20 \%$. Oleic acid was the second most abundant fatty acid in Codium dimorphum and also important in the other two species. 
Total polyunsaturated fatty acids (PUFA) with C16, $\mathrm{C} 18$, and $\mathrm{C} 20$ accounted for $18 \%$ to $42 \%$ in the three species studied. Codium fernandezianum was the species with the higher proportion of PUFA content. The genus contains linolenic acid as the dominant C18 PUFA and relatively high percentages of linoleic acid. Hexadecatrienoic acid, a possible chemotaxonomic character of the species of Codium, was found in relatively high amounts ( $7.2 \%$ to $9.5 \%)$ in all species while the hexadecatretraenoic acid (C16:4) was not detected.

Codium dimorphum, C. fernandezianum and C. fragile were found to be slightly distinguishable from one another in terms of their fatty acid amount (Table 1, Fig. 1).

\section{Discussion}

Representatives of the genus Codium collected from a variety of places around the world have been investigated due to their fatty acid contents (Hainaux et al. 1998, Xu et al. 1998, Dembitsky et al. 2003, Khotimchenko 2003). However, there is just one published research on the species living in Chile. And the fatty acid composition of the two endemic species, Codium dimorphum and $C$. fernandezianum has not been reported previously.

As reported worldwide for green macroalgae all three Codium species had high $\mathrm{C} 16$ and $\mathrm{C} 18$ contents (Aliya et al. 1992, Hainaux et al. 1998, Graeve et al. 2002, Li et al. 2002, Khotimchenko 2003, Ortiz et al. 2009) (Table 1). Several studies have shown palmitic acid (C16:0) to be the main saturated fatty acid of green macroalgae. The same pattern has been observed globally and in the present study for Codium spp. (Al-Hasan et al. 1991, Aliya et al. 1992, Khotimchenko 1993, Xu et al. 1998).

Thus, macroalgae of the genus Codium have palmitic, oleic, linolenic, linoleic and hexadecatrienoic acids as important components totalling more than $50 \%$ of all fatty acids. The total content of saturated fatty acids (SAFA) and polyunsaturated fatty acids (PUFA) was higher than the monounsaturated fatty acids (MUFA). Codium fernandezianum was the species with the higher proportion of PUFA content (Table 1). A similar proportion in the levels of saturation of the fatty acids was previously reported in other 16 different species of Codium from different geographical locations (see Dembitsky et al. 2003, Khotimchenko 2003). And it seems that the specific features of the fatty acid composition typical of the genus remain constant.

In accordance to other studies of fatty acid configuration on Chlorophyta, the genus contains linolenic acid as the dominant $\mathrm{C} 18$ PUFA, relatively high percentages of linoleic acid and minute amounts of 18:4 (Khotimchenko 2003), the latter fatty acid was not detected in this study. Between the members of Bryopsidales the monounsaturated fatty acid oleic acid (C18:1) has also a chemotaxonomic importance, it is described to be present in high amounts in the genus Codium (Khotimchenko 2003), as could also be shown in the present study. The presence of arachidonic acid (C20:4, Table 1) shows that the three studied Codium species are capable of synthesizing larger PUFAs.

A strong relationship has been found between biogeographical conditions and fatty acid contents. Environmental effects have to be taken in account. Salinity, temperature, solar radiation, nutrient availability, and environmental pollution affect the physiological state of the algae and thereby affect the fatty acid composition (Teoh et al. 2004). Al-Hasan et al. (1991) reported variations in macroalgae fatty acid concentrations, but not in the composition pattern, when the temperature varied. Also an increased desaturation of fatty acids was detected in various species of brown macroalgae during the winter season (Pohl \& Zurheide 1979).

The function of fatty acids in algae is related to cell membranes, energy storage and metabolic processes (Orhan et al. 2003). The function of polyunsaturated C20 fatty acids is not completely clear, although they are important components of the lipids of chloropastidial thylakoids (AlHasan et al. 1991). Fatty acids may play important roles in the ecology of aquatic ecosystems: Research on the biological activity of fatty acids has shown antibacterial activity of oleic acid, lauric acid, palmitic acid, linoleic acid, and linolenic acid, among others (Kabara et al. 1972). Also, they can play a role in defense (Jüttner 2001), and are capable to control microalgal growth (DellaGreca et al. 2001). A mixture of saturated, monosaturated or polyunsaturated fatty acids in microalgae has shown to be active against green microalgae and phytoplanktonic organisms (Ikawa 2004).

In regards to chemotaxonomy, hexadecatrienoic acid (C16:3) was found in the three species studied, although hexadecatetraenoic acid (C16:4) was not. This apparently important chemotaxonomic marker of Codium spp. was present in a relatively high amount (7-9\%) in the three studied species as demonstrated for other studies around the world (Khotimchenko 2003). This agrees Al-Hassan et al. (1991), Khotimchenko (1993) and Xu et al. (1998). However, Ortiz et al. (2009) could not detect these two fatty acids in Codium fragile from Chile in an earlier study. Extensive analyses on variability of fatty acids in Codium carried out in several species around the world (Dembitsky et al. 2003) have not been included for 
Southamerican species. Because chemical composition vary with biogeographical conditions, it is interesting to study the chemical composition of both endemic and introduced species growing in this part of the world.

Recently, molecular studies have helped to clarify a number of long standing issues related to the phylogeny of Bryopsidales (Lam \& Zechman 2006). Diverse information like chemical composition, morphology, life cycle and other molecular studies will allow us to understand the evolution in these diverse green algae (Khotimchenko 2003). Morphology in macroalgae can be quite plastic, and may be dependent upon environmental factors including light, wave action and position in the water column, among others. This often leads to difficulties in taxonomical identifications when basing only in morphology. Chemotaxonomic approaches can be complements for taxonomy, as it has been a successful technique applied on brown algae (Laird et al. 2010). Thus, chemotaxonomy of certain metabolites, including pigments, terpenes, sterols and fatty acids, should also be taken into account for identification purposes (Vallim et al. 2005)

The three Codium species analyzed in this study $(C$. fernandezianum, $C$. fragile and $C$. dimorphum) come from environments with different physico-chemical characteristics (Santelices \& Meneses 2000). These algae presented a similar pattern between them and between configurations described elsewhere for this genus, though the particular amounts could differ. The observed result is therefore, interesting from both a biochemical and chemotaxonomic point of view. The present work contributes to the global information on the chemical composition of the genus.

Fatty acids appear to be a promising tool to study trophic relationships in the marine environment (Silva et al. 1984), as the lipids composition of macroalgae is largely made up by characteristic PUFAs (Graeve et al. 2002). According to Trowbridge (1998), the first step is to integrate chemical and ecological information, in order to get a better understanding of the ecological interactions among algae and consumers, competitors and symbionts. Furthermore, compounds such as vegetable lipids, fatty acids and also volatile compounds offer valuable information for designating taxonomic positions (Dembitsky et al. 2003).

Another important branch that is newly arisen is the use of these compounds for example in cosmetics and for synthesizing eicosanoid hormones (Khotimchenko 1998). Lipids determination in algae is critical for the possible industrial exploitation of species rich in specific, commercially valuable steroids and/or carotenoids (Pollesello et al. 1992). Exhaustive studies are imperative to understand the natures of these compounds and to obtain new biologically active molecular prototypes that can be useful to humans (Silva et al. 1984). Algae are an important resource to consider.

\section{ACKNOWhedgments}

The authors wish to thank the Dirección de Postgrado, Universidad de Concepción, Chile and Proyecto Anillo ACT-38. We also thank Mr. Oscar Alcalde (Manager Director of Cultivos Caldera, Caldera, Chile) and Dr. Paula Neill for their help in samplings, and Dr. T. Staufenberger for critical reading and corrections of this manuscript.

\section{LiTERATURE CITED}

Al-Hasan RH, FM Hantash \& SS Radwan. 1991. Enriching marine macroalgae with eicosatetranoic (arachidonic) and eicosapentaenoic acids by chilling. Apply Microbiology and Biotechnology 35: 530-535.

Aliya R, M Shameel, K Usmanghani \& VU Ahmad. 1991. Analysis of fatty acids from Codium iyengarii (Bryopsidophyceae). Pakistan Journal of Pharmaceutical Sciences 4(2): 103-111.

Aliya R, M Shameel, K Usmanghani \& VU Ahmad. 1992. Comparative composition of fatty acid of Codium decorticatum and C. flabellatum (Bryopsidophyceae). Pakistan Journal of Pharmaceutical Sciences 5(1): 87-99.

Caccamese S, D Azzolina, G Furnari, M Cormaci \& S Grasso. 1981. Antimicrobial and antiviral activities of some marine algae from eastern Sicily. Botanica Marina 24: 365-367.

Campbell SJ. 1999. Occurrence of Codium fragile subs. tomentosoides (Chlorophyta: Bryopsidales) in marine embayments of southeastern Australia. Journal of Phycology 35: 938-940.

DellaGreca M, A Fiorentino, M Isidori, $P$ Monaco, F Temussi \& A Zarrelli. 2001. Antialgal furano-diterpenes from Potamogeton natans L. Phytochemistry 58: 299-304.

Dembitsky VM, H Rezankova, T Rezanka \& LO Hanus. 2003. Variability of the fatty acids of the marine green algae belonging to the genus Codium. Biochemical Systematics and Ecology 31: 1125-1145.

Graeve M, G Kattner, C Wiencke \& U Karsten. 2002. Fatty acid composition of Arctic and Antarctic macroalgae: indicator of phylogenetic and trophic relationships. Marine Ecology Progress Series 231: 67-74.

Hainaux F, S Rohan, M Simon, G Bourbigot \& Y De-RoeckHoltzhauer. 1998. Détermination de la composition des 
acides gras d'une algue sponqieuse du genre Codium. Oléagineux Corps gras Lipides 5: 237-240.

Hoffmann A \& B Santelices. 1997. Flora marina de Chile central, 434 pp. Ediciones Universidad Católica de Chile, Santiago.

Ikawa M. 2004. Algal polyunsaturated fatty acids and effects on plankton ecology and other organisms. UNH Center for Freshwater Biology Research 6: 17-44.

Ip C. 1997. Review of the effects of trans fatty acids, oleic acid, n-3 polyunsaturated fatty acids, and conjugated linoleic acid on mammary carcinogenesis in animals. American Journal of Clinical Nutrition 66(Suppl. 6): 1523-1529.

Jüttner F. 2001. Liberation of 5,8,11,14,17-eicosapentaenoic acid and other polyunsaturated fatty acids from lipids as a grazer defense reaction in epilithic diatom biofilms. Journal of Phycology 37: 744-755.

Kabara JJ, DM Swieczkowski, AJ Conley \& JP Truant. 1972. Fatty acids and derivatives as antimicrobial agents. Antimicrobial Agents and Chemotherapy 2(1): 23-28.

Khotimchenko SV. 1993. Fatty acids of green macrophytic algae from the sea of Japan. Phytochemistry 32: 12031207.

Khotimchenko SV. 1998. Fatty acids of brown algae from the Russian Far East. Phytochemistry 49: 2363-2369.

Khotimchenko SV. 2003. Fatty acids of species in the genus Codium. Botanica Marina 46: 456-460.

Laird DW, S Bennett, B Bian, B Sauer, K Wright, V Hughes \& IA van Altena. 2010. Chemical investigation of seven Australasian Cystophora species: new chemistry and taxonomic insights. Biochemical Systematics and Ecology 38: 187-194.

Lam DW \& FW Zechman. 2006. Phylogenetic analyses of the Bryopsidales (Ulvophyceae, Chlorophyta) based on rubisco large subunit gene sequences. Journal of Phycology 42: 669-678.

Orhan I, B Sener \& T Atici. 2003. Fatty acid distribution in the lipoid extracts of various algae. Chemistry of Natural Compounds 39: 167-170.

Ortiz J, E Uquiche, P Robert, N Romero, V Quitral \& C Llantén. 2009. Functional and nutritional value of the Chilean seaweeds Codium fragile, Gracilaria chilensis and Macrocystis pyrifera. European Journal of Lipid Science and Technology 111: 320-327.
Pohl P \& F Zurheide. 1979. Fatty acids and lipids of marine algae and the control of their biosynthesis by environmental factors. In: Hoppe HA, T Levring \& Y Tanaka (eds). Marine algae in pharmaceutical science, pp. 473-523. Walter de Gruyter, Berlin \& New York.

Pollesello P, R Toffani, E Murano, S Paoletti, R Rizzo \& BJ Kuam. 1992. Lipids extracts from different algal species: 1H-and13 C-NMR spectroscopic studies as a new tool to screen differences in the composition of fatty acids, sterols and carotenoids. Journal of Applied Phycology 4: 315-322.

Ramírez ME \& B Santelices. 1991. Catálogo de algas marinas bentónicas de la costa temperada del Pacífico de Sudamérica, Monografías Biológicas 5: 1-437. Facultad de Ciencias Biológicas, Universidad Católica de Chile, Santiago.

Sanhueza JC, SK Nieto \& AB Valenzuela. 2002. Conjugated linoleic acid: a trans isomer fatty acid potentially beneficial. Revista Chilena de Nutrición 29: 98-105.

Santelices B \& I Meneses. 2000. A reassessment of the phytogeographic characterization of temperate Pacific South America. Revista Chilena de Historia Natural 73: 605-614.

Silva M, F González \& S Pantoja. 1984. Química de la flora y fauna de Chile. In: Aguilera JM, JA Guzmán \& M Rutman (eds). Recursos renovables chilenos: una visión multidisciplinaria, pp. 111-131, Ediciones Universidad Católica de Chile, Santiago.

Teoh ML, WL Chu, H Marchant \& SM Phang. 2004. Influence of culture temperature on the growth, biochemical composition and fatty acid profiles of six Antarctic microalgae. Journal of Applied Phycology 16: 421-430.

Trowbridge CD. 1998. Ecology of the green macroalga Codium fragile (Suringar) Hariot 1889: invasive and noninvasive subspecies. Oceanography and Marine Biology: an Annual Review 36: 1-64.

Vallim MA, JC De Paula, RC Pereira \& VL Teixeira. 2005. The diterpenes from dictyotacean marine brown algae in the Tropical Atlantic American region. Biochemical Systematics and Ecology 33: 1-16.

Xu XQ, VT Hung, G Kraft \& J Beardall. 1998. Fatty acids of six Codium species from southeast Australia. Phytochemistry 48: 1335-1339.

Recibido el 7 de octubre de 2009 y aceptado el 1 de junio de 2010 